\title{
Legal Protection of Mining Workers from The Perspective of Mining and Labor Law
}

\author{
Saefullah \\ Student at Doctoral Program of Law \\ Universitas Borobudur \\ Jakarta, Indonesia \\ saefullah1980@gmail.com
}

\author{
Faisal Santiago \\ Universitas Borobudur \\ Faculty of Law \\ Jakarta, Indonesia \\ faizalsantiago@borobudur.ac.id
}

\begin{abstract}
In Law No. 4 of 2009 on Mineral and Coal Mining, where one of the goals of the Law No. 4 Year 2009 is to increase the income of local communities, regions, and countries, and create jobs for the greatest welfare of the people. The regulation then the mining activities will absorb the workforce of the mining area community, this brings a positive impact for the community of mineral and coal mining areas, because it is able to raise the standard of living of mining and mineral mining areas. However, the mining community in general is a community that comes from rural areas whose quality of education is still lacking. Lack of education and lack of understanding of the workforce of the mining area poses a threat to mineral and coal mining workers. Mining activity is one of the land of money producers and workers who can be categorized as dangerous. The hazardous work Brings anxiety and questions by miners and coal miners about "what legal rights and protections they must have to ensure safety while working and for the welfare of life". There have been rules governing mineral and coal mining activities, namely Law No. 4 of 2009 on mineral and coal mining. Rules on the protection of workers are also generally regulated in Law No. 13 Year 2003 on Manpower. Employment protection of mineral and coal mining by mining license holders and how to create community welfare around mineral and coal mining areas. Workers who work in the management of mineral and coal mining are valuable assets owned by holders of Mining and Coal Mining Business Licenses (companies). To be able to produce a good mining product, the holder of Mining and Mineral Mining Business License must provide comfort for workers through protection. Protection granted by holders of Mining and Coal Mining Business Licenses, namely: social protection or health protection; technical protection or safety protection; and economic protection or social security. Management of natural resources in Indonesia is managed to develop human resources in Indonesia and improve the country's economy, as well as for the welfare of the people of Indonesia. With the existence of education for the community of mineral and coal mining area, this will increase the involvement of the community in the implementation of mineral and coal mining management and improve the ability owned by the workforce, to pre vent the occurrence of work accidents, and is one way to improve the standard of living or prospering the community of mining areas of mineral and coal.
\end{abstract}

Keywords-legal protection, manpower, mining.

\section{INTRODUCTION}

Law No. 4 of 2009 on Mineral and Coal Mining, which is one of the objectives of the Act. No. 4 Year 2009 is to increase the income of local communities, regions, and countries, and create jobs for the maximum welfare of the people.

With such regulation, mining activities will absorb the workforce of the mining community, this has a positive impact on mineral and coal mining communities, as it is able to raise the standard of living for mining and coal mining communities. However, the mining community in general is a community that comes from rural areas whose quality of education is still lacking. Lack of education and lack of understanding of the workforce of the mining area poses a threat to mineral and coal mining workers.

Mining activity is one of the land of money producers and workers who can be categorized as dangerous. Why is it said dangerous? The answer is because it uses dangerous tools such as: heavy equipment, chemicals, explosives, etc. In addition to equipment, mineral and coal mining activities are also directly related to nature, where we know together that the natural state can change at any time and is very difficult to predict. Bringing anxiety and questions by mineral and coal mining workers about

"what legal rights and protections they should have to ensure safety while working and for the welfare of life". There have been rules governing mineral and coal mining activities, namely Law No. 4 of 2009 on mineral and coal mining. Rules on the protection of workers are also generally regulated in Law Number 13 Year 2003 on Manpower. But the livelihoods of communities around the mining area are limited to information and knowledge about the legal protections they ought to have and there are still doubts from mining communities to engage or develop themselves through the management of mineral and coal mining, due to limited education

which makes the community or labor of the region around the mine afraid of working accidents. Another reason is that labor from large mining areas is only a laborer or laborer, due to the limited ability of the workforce that comes from around the mineral and coal mining areas, and whether the support program to improve the capability of the workforce areas around mineral and coal mining. Natural 
resources owned by Indonesia should be able to empower and improve the quality of human resources in Indonesia.

The State of Indonesia is a state of law and the State of Indonesia is responsible for the welfare of the Indonesian people, including protecting Indonesia's natural resources and human resources and in the development of communities surrounding mineral and coal mining areas not knowing every right and protection afforded by the law for the territorial community around mining, as well as lack of education and programs for the development of mineral and coal mining communities.

\section{RESEARCH METHODS}

This paper is a method of research using normative juridical method of legal research conducted by examining library materials or secondary data as a basic material to be investigated by conducting a search on the rules and the literature related to the problems studied.

\section{PROBLEMS}

1. How is the protection of mineral and coal mining workforce by mining license holders?

2. How to create community welfare around mineral and coal mining areas?

\section{DISCUSSION}

\section{A. Protection of Mineral and Coal Mining Workers granted by Holders of Mining Business License}

These types of job protection will be discussed one by one to make it easier for us to understand about the protection of the workers.

\section{1) Occupational Health Protection or Social Protection}

Health is a healthy, physical, mental, spiritual and social condition that enables everyone to live socially and economically productive. While occupational health herein is a type of social protection because these provisions concerning occupational health relate to social society, namely rules that intend to impose restrictions on the power of employers to treat workers or laborers altogether without regard to applicable norms, regardless of the worker or his worker as a God-given creature of human rights. Occupational health intends to protect or safeguard workers or workers from the occurrence or circumstances of employment which adversely affect their health and morals in the case of workers or laborers performing their work.

As a form of concern for health and to protect human rights in health, the enactment of a law on health, namely Law Number 36 Year 2009 on Health. Working time according to the provision of Article 77 of Law no. 13 of 2003 on Manpower is as follows:

1) 7 (seven) hours 1 (one) day and 40 (forty) hours 1 (one) week for 6 (six) working days in 1 (one) week;

2) 8 (eight) hours 1 (one) day and 40 (forty) hours 1 (one) week for 5 (five) working days in 1 (one) week.

The working hours mentioned above must be interspersed with at least 30 (thirty) minutes of rest time after the worker or laborer has worked four hours in a row. Term time rests in the Act. No. 13 Year 2003 concerning Employment is known as a break in Article 79, which reads:
Rest between working hours, at least half an hour after working for 4 (four) hours continuously and the break time does not include working hours.

\section{2) Protection of Occupational Safety or Protection}

Technical protections commonly called occupational safety safeguards have specific rules governing occupational safety. On January 12, 1970, Law No. 1 of 1970 on Work Safety was enacted, with the following considerations:

1) That every worker shall be entitled to protection for his safety in performing work for the welfare of life and enhancing national production and productivity;

2) That every other person at work should be assured of his safety;

3) That every production source should be used and used safely and efficiently;

4) That in connection with this, all efforts must be made to foster the norms of working protection;

5) That the guidance of such norms should be realized in the law which contains general provisions on work safety in accordance with the development of society, industrialization, engineering and technology.

\section{3) Social Security or Economic Protection}

Workers' Social Security is a protection for labor in the form of compensation in the form of money as a substitute for some of the lost or diminished income and services as a result of events or circumstances experienced by workers in the form of work accidents, illness, pregnancy, maternity, old age, and die. Just as occupational safety protection, economic protection or so-called social security protection of labor gets particular attention in the form of protection.

Protection of social security of workers has a special rule contained in Act No. 3 of 1992 on Social Security of Labor. However, with the enactment of Law Number 24 Year 2011 on the Social Security Administering Body, Law No. 3 of 1992 on Social Security of Workers is revoked and declared no longer valid. BPJS Employ ment begins to operate a work accident, pension, pension and death insurance program for Participants, in addition to program participants managed by PT TASPEN (Persero) and PT ASABRI (Persero), in accordance with the provisions of Articles 29 to Article 46 of Law Number 40 Year 2004 regarding National Social Security System (State Gazette of the Republic of Indonesia Year 2004 Number 150, Supplement to State Gazette of the Republic of Indonesia Number 4456), no later than 1 July 2015.

Thus, starting on July 1, 2015, the State of Indonesia uses Law Number 24 of 2011 on the Social Security Administering Body, abbreviated as BPJS in terms of providing social security coverage to labor. The bas is of the coming into force of the Act. No. 24 Year 2011 on BPJS are:

1) That the national social security system is a state program aimed at providing assurance of social protection and welfare for all people;

2) That in order to realize the objectives of the national social security system, it is necessary to establish an organizing body in the form of a legal entity based on the principle of mutual cooperation, non-profit, transparency, prudence, accountability, portability, compulsory membership, trust funds, and the results 
of the management of the entire social security fund for development programs and for the greatest interest of the participants;

3) Whereas pursuant to Article 5 paragraph (1) and Article 52 of Law Number 40 Year 2004 regarding National Social Security System, a Social Security Admin istering Body shall be established with a Law which is the transformation of the four State-Owned Enterprises to accelerate the implementation of the social security system national for all Indonesian people.

\section{B. Community Welfare of Mineral and Coal Mining Areas through Working Education for Mining and Mineral Coal Workers, Judging from the Law. No. 4 Year 2009 About Mineral and Coal Mining}

Labor is a very dominant capital in the success of development programs. However, employment issues in Indonesia are increasingly comple $\mathrm{x}$ as the population increases, requiring serious attention from various parties. With the mining sector of minerals and coal utilizing the natural resources of Indonesia opens opportunities for the people of Indonesia to get a job, to develop themselves and improve the standard of living. However, the involvement of local manpower in the management of mineral and coal mining business activities is still limited to rough chase, the government and entrepreneurs of mineral and coal mining are still minimal to seek to develop local workforce into skilled labor through job education and apprenticeship.

Limitations of knowledge and understanding possessed by local communities of mineral and coal mining areas, cause people to remain silent and follow what is there, without realizing and understanding what things they can accept. In Law No. 4 of 2009 on Mineral and Coal Mining, there are 4 (four) important goals to be achieved by the State of Indonesia, namely:

a. The first intention is that this law intends to strengthen the decentralization of mining authority from the regional centers previously regulated in the PP. No. 75 Year 2001 along with the process of regional autonomy. At the same time, it is also a matter of intention to improve the management of mining which includes the regulation of the procedure of granting mining permits and supervision of mining activities at the central, provincial, and district level. Improvement in licensing procedure is one of them by applying the auction process to the mineral and coal mining business permit area. This regulation seeks to eliminate conflicts of interest between the government and business actors;

b. The second intent is that the law intends to reinforce the government's protection of the possible social and environmental impacts of mining. The law requires companies to create community empowerment plans, reclamation plans and post-mining activities, as well as evidence of company's firmness with the obligation of placement of reclamation guarantee funds and postmining activities;

c. The third purpose is that this law is to enlarge the benefits of the general mining sector for the State and the public. Increasing the profitability of the mining sector for the state and the community is done through three ways: first is through the optimization of local resource involvement in mining activities both human resources, procurement of goods and services of local products and the involvement of local bisnin entities in the mining business chain; second is through the obligation to divest the shares of a foreign company at a minimum of $20 \%$ to $51 \%$ to the domestic business entity; and third is by requiring mining companies to conduct domestic mineral processing to increase added value; and

d. The fourth purpose is that this law wants to direct the Indonesian nation to carry out a strategy in the globalization of mining business through the provision of state mining areas. Because, not all mining potentials should be exploited, production must see market needs for price control, should look at current and long-term national strategic interests, as well as economy security and sustainability for industry and future generations.

Intent to be achieved by Indonesia through the Act. No. 4 of 2009 on Mineral and Coal Mining is basically for the economic progress of the country and the welfare of Indonesian society. 'a prosperous society is a mirror of a prosperous country' This piece reminds us that how much development there is in Indonesia, how much of the results Indonesia receives from various sectors of economic development, and how many richest people in the world exist in Indonesia, prosperity for the Indonesian people, if the people of Indonesia are still living in a poor living and there is still discrimination of social status.

Indonesia has a wealth of abundant natural resources, but Indonesia's human resources still need development. With the development of the Indonesian economic sector through the management of mineral and coal mining business activities and the existence of special rules to oversee the running of the management of these business activities. So it is expected that through the sector of mineral mining and coal can increase the economic value of Indonesia and develop the potential of human resources in Indonesia, which in this case aimed at empowering communities of mineral and coal mining areas. Community Empowerment is an effort to improve the ability of the community, both individually and collectively, in order to become better level of life. There are several efforts made by the government in the development and empowerment of mining circle communities through the mineral and coal mining sector.

This can be seen in the strategic objectives of the minerals and coal ministry contained in the strategic plan of the Directorate General of Minerals and Coal in 2010-2014, among others related to the development and empowerment of mining communities, namely:

1) Improved role of mineral and coal sub-sector in regional development; and

2) Improvement of the effect of chain / employment.

The above strategic objectives are further elaborated in the following targets related to the development and empowerment of mining communities:

1) The realization of the increasing role of the general mining sub-sector (minerals and coal) in regional development;

2) The realization of national empowerment; 
3) Realization of labor absorption; and

4) Implementation of mineral and coal mining activities that meet safety requirements.

In addition, efforts to develop and empower the communities of mining areas can also be seen in the provisions of the Act. NO. 4 of 2009 on Mineral and Coal Mining. In the Act. No. 4 of 2009, there are several articles that contain the development and empowerment of the community, which in this case is the community of mining areas, namely Article 141; Article 3; Articles 6, 7 and 8; Article 39; Article 96; and Pesal 106. From the provisions of the rules of mineral mining and coal through the Act. No. 4 Year 2009 on the development and empowerment of communities carried out for 2 (two) important goals, namely: the safety of mining operations and improvement of living standards.

The development and empowerment of communities of mineral and coal mining areas in this case can be implemented through employment and employment opportunities for mineral and coal mining workers. Employment opportunities in accordance with the provisions of the Act. No. 4 of 2009 Article 106 which takes precedence is the workforce of Indonesia. However, the ability of Indonesian labor is basically placed on the work capacity as a manual laborer, due to the lack of education owned by the mining area community, thus unable to support the opportunities, capabilities and expertise possessed by the workforce coming from mineral and coal mining areas. Limitations of education are the limiting factors in the involvement of mining communities in the implementation of the management of mineral and coal mining business activities. Utilization of Indonesia's natural resources through mineral and coal mining if carried out with the provisions of the right rules will bring prosperity to the people of Indonesia and able to improve the Indonesian economy.

\section{CONCLUSIONS}

1. Workers who become workers in mineral and coal mining business activities are very valuable assets, owned by holders of mineral and coal (mining license). To be able to produce a good mining product, holders of mineral and coal mining license must provide comfort for workers through protection. Protection provided by holders of mineral and coal mining license, namely: social protection or health protection; technical protection or safety protection; and economic protection or social security.

2. Managing natural resources in Indonesia is managed to develop human resources in Indonesia and improve the country's economy, as well as for the welfare of the people of Indonesia. With the existence of working education for the community of mineral and coal mining area, this will increase the involvement of the community in the implementation of mineral and coal mining management and improve the ability possessed by the workforce, to prevent the occurrence of work accidents, and is one way to improve the standard of living or prosper communities of mineral and coal mining areas.

\section{REFERENCES}

[1] A D Utami Ida, et.al,Perlindungan Hukum Terhadap Pekerja Dalam Perjanjian Kerja Dengan Sistem Outsourcing Di Indonesia, Makalah, Universitas Udaya, Bali. Undang-Undang Dasar Negara Republik Indonesia T ahun 1945.

[2] Abdulkadir Muhammad, Hukum Dan Penelitian Hukum, Citra Aditya Bakti, Bandung, 2004.

[3] Adrian Sutedi, Hukum Pert ambangan, Sinar Grafika, Jakarta, 2016.

[4] Ahmad Redi, Hukum Pertambangan, Gramata Publishing, Jakarta, 2014.

[5] Eko Wahyudi, et.al, Hukum Ketenagakerjaan, Sinar Grafika, Jakarta 2016

[6] H Salim HS \& Erlies, Septiana Nurbani, Penerapan Teori Hukum Pada Penelitian Tesis Dan Disertasi, PT RajaGrafindo Persada, Jakarta, 2013.

[7] H Salim HS, Hukum Pertambangan Mineral dan Batubara, Sinar Grafika, Jakarta, 2014.

[8] H Salim HS,Hukum Pertambangan Di Indonesia, PT RajaGrafindo Persada, Jakarta, 2014.

[9] Nandang Sudrajat, Teori Dan Praktik Pertambangan Indonesia, Pustaka Yustisia, Yogyakarta, 2013.

[10] Nasution Bahder, J Metode Penelitian Ilmu Hukum, Mandar Maju, Bandung, 2008.

[11] Otong Rosadi, Pertambangan Dan Kehutanan Dalam Perspekt if Cita Hukum Pancasila, Thafa Media, Yogyakarta, 2012.

[12] Peter M Marzuki, Penelitian Hukum, Kencana, Jakarta, 2009.

[13] Rachmat Trijono, Pengantar Hukum Ketenagakerjaan, Papas Sinar Sinanti, Jakarta, 2014.

[14] Titon Kurnia, S, et.al, Pendidikan Hukum, Ilmu Hukum Dan Penelitian Hukum Di Indonesia, Pustaka Pelajar, Yogyakarta, 2013.

[15] Yopi Gunawan, \& Kristian, Perkembangan Konsep Negara Hukum dan Negara Hukum Pancasila, Refika Aditama, Bandung, 2015

[16] Yovita A Mangesti \& Bernard L, Tanya, Moralitas Hukum, Genta Publishing, Yogyakarta, 2014.

[17] Zaeni Asyhadie, , Hukum Kerja Hukum Ketenagakerjaan Bidang Hubungan Kerja, PT RajaGrafindo Persada, Jakarta, 2013.

[18] Indonesia, Law of the Republic of Indonesia Number 3 of 1992 concerning Social Security of Labor.

[19] ___ Law of the Republic of Indonesia Number 4 of 2009 on mineral and coal mining.

[20] ____ Law of the Republic of Indonesia Number 13 Year 2003 on Manpower.

[21] ___ Law of the Republic of Indonesia Number 24 Year 2011 regarding Social Security Administering Body.

[22] ___ Law of the Republic of Indonesia Number 36 Year 2009 on Health.

[23] _____ Law of the Republic of Indonesia Number 40 Year 2004 regarding Social Security System. 